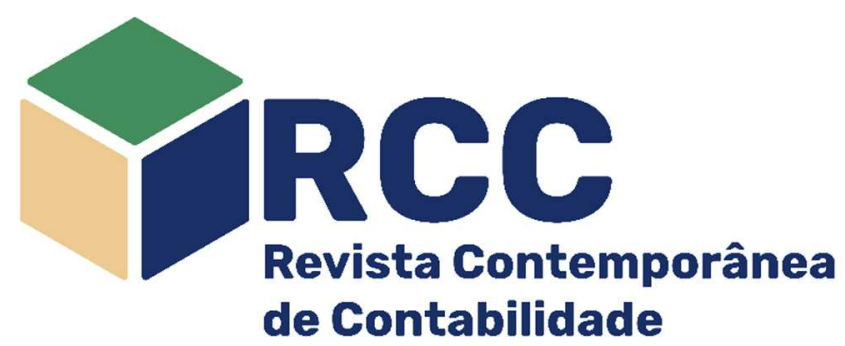

\title{
Racionalidades substantiva e instrumental nas decisões de peritos contadores, sob a lente da teoria da ação comunicativa
}

\author{
Substantive and instrumental rationalities in accounting experts' decisions, under the lens of the \\ communicative action theory
} Racionalidades sustantivas e instrumentales en las decisiones de expertos en contabilidad, bajo la
lente de la teoría de la acción comunicativa

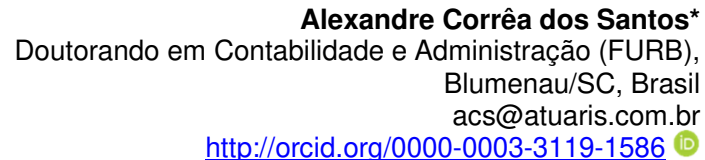

Alexandre Corrêa dos Santos* acs@atuaris.com.br
Nelson Hein

Doutor em Engenharia de Produção (UFSC) Professor do Programa de Pós-Graduação em Contabilidade (FURB), Blumenau/SC, Brasil hein@furb.br http://orcid.org/0000-0002-8350-9480 (i)

Endereço do contato principal para correspondência* Rua Ametista no 289, Jardim Brasília, CEP: 86200-000 - Ibiporã/PR, Brasil

\section{Resumo}

A teoria da ação comunicativa discute o mundo a partir da realidade subjetiva, histórica e social em um contexto de verdade, pautada na emancipação do ser humano por meio de relações sociais justas e legítimas. Enquanto meio de entendimento dialógico, o campo do trabalho representa uma ligação entre os sujeitos e seus interesses e, nesta relação estão os peritos contadores, com o múnus de promover o equilíbrio da justiça. Este estudo objetiva mensurar o nível das racionalidades substantiva e instrumental presente nas decisões de peritos contadores e verificar possíveis pontos de tensionamento. Esta pesquisa é descritiva, exploratória e quali-quanti. Os dados foram coletados do cadastro nacional de peritos contadores (CNPC), dos cadastros dos tribunais de justiça estaduais e das associações de peritos. Os resultados analisados por meio da técnica multicritério DP2 mostram baixa presença da racionalidade substantiva nas decisões de peritos contadores.

Palavras-chave: Perícia contábil; Racionalidade substantiva; Racionalidade instrumental

\section{Abstract}

The theory of communicative action discusses the world from the subjective, historical and social reality in a context of truth, based on the emancipation of the human being through just and legitimate social relations. As a means of dialogical understanding, the field of work represents a link between the subjects and their interests and, in this relationship are inserted the accounting experts, with the task of promoting the balance of justice. This study aims at measuring the level of substantive and instrumental rationalities present in accounting expert decisions and to verify possible tensioning points. This research is descriptive, exploratory and qualiquanti. Data were collected from the national register of accountants expert (CNPC), the low state courts and proficient associations. The results analyzed using the DP2 multicriteria technique show low presence of substantive rationality in accounting expert decisions.

Keywords: Accounting legal advices; Substantive rationality; Instrumental rationality

\section{Resumen}

La teoría de la acción comunicativa discute el mundo desde la realidad subjetiva, histórica y social en un contexto de verdad, basada en la emancipación del ser humano a través de relaciones sociales justas y legítimas. Como medio de comprensión dialógica, el campo de trabajo representa un vínculo entre los sujetos y sus intereses y en esta relación, están los expertos en contabilidad, con la tarea de promover el equilibrio de la justicia. El objetivo de este estudio es medir el nivel de racionalidades sustantivas e instrumentales presentes en las decisiones de expertos en contabilidad y los verificar posibles puntos de tensión. Esta 
investigación es descriptiva, exploratoria y cualitativa. Los datos se obtuvieron del registro nacional de contadores expertos (CNPC), los registros de los tribunales estatales y las asociaciones de expertos. Los resultados analizados utilizando la técnica de múltiples criterios DP2, muestran una baja presencia de racionalidad sustantiva en las decisiones de expertos en contabilidad.

Palabras clave: Pericia contable; Racionalidad sustantiva; Racionalidad instrumental

\section{Introdução}

A natureza do trabalho jurídico ligada à obrigação da emissão de opinião em litígios, coloca os magistrados diante de fenômenos pertencentes à outros ramos do conhecimento, como a contabilidade, a medicina, a economia, a psicologia, etc. Portanto, eles consideram que o trabalho dos peritos é fundamental para as decisões jurídicas (OLIVEIRA; ROJAS; NUNES, 2017; FILARDO et al., 2018) e recorrem ao auxílio de experts para a emissão de opinião que subsidie questões de natureza técnica (ORNELAS, 2011; CFC, 2015).

Porém, no Brasil pesquisas empíricas tem revelado que o conteúdo apresentado pelos peritos contadores em seus laudos não tem se mostrado suficiente (SANTOS et al., 2013), o que sinaliza que o trabalho pericial pode ser melhorado para maximizar o poder de contribuição da prova pericial para a decisão judicial e, desta forma, favorecer a consolidação desta função contábil (MEDEIROS et al., 2018).

Em relação ao critério de qualidade do trabalho, Santos, Taveira e Penha (2017) apontam que os magistrados escolhem, respectivamente, peritos cujas características refletem o seu nível de conhecimento técnico, respeitam o prazo para a conclusão da perícia, apresentam laudo de qualidade com informações claras e precisas, prezam pela estrutura do laudo e demonstram eficácia na solução de litígios.

Este conjunto de pressupostos em relação ao "perito ideal", segundo a visão dos magistrados, apoiase em uma abordagem positivista, em que a fé na ciência do perito reside nela mesmo, ou seja, o aspecto metodológico, empírico e racionalista parece ser o fundamento da objetivação e comprovação do conhecimento pericial (MEDEIROS; MARQUES, 2003).

No entanto, no trabalho pericial a racionalidade em si mesma pode não ser suficiente para suportar um processo de construção de conhecimento (HABERMAS, 1982) em que os interesses de todos os sujeitos que se relacionam, sejam equalizados com o fim de se buscar o equilíbrio e o consenso em relação à razão. Isto não quer dizer que o perito deve considerar todas as reinvindicações como legítimas, mas, sua opinião deve ser construída a partir de relações processuais com interesses distintos.

Diante disso, há o risco de que o perito, ao apoiar-se unicamente em uma visão racionalista, analise e faça conclusões de natureza instrumental e individualista em relação aos fenômenos que deve emitir opinião, de forma a desprezar o plano das interações com os outros sujeitos envolvidos com o resultado do trabalho pericial (HABERMAS, 1982).

A partir disso, o pensamento de Habermas (1997) ajuda na compreensão do campo pericial sob a ótica da teoria da ação comunicativa, tendo em vista possíveis interações presentes no trabalho pericial, ligadas à perspectiva da linguagem do sujeito perito na lida com as partes processuais em seus aspectos objetivo, social e subjetivo, o que permite aprofundar na relação entre razão e equilíbrio da justiça.

Tal expectativa neste estudo advém da busca da verdade, que Habermas a define como uma construção processual e contextual, cujo consenso deve estar relacionado ao mundo objetivo, expresso na natureza, nos fatos e nas experiências concretas, mas não deve ser separada da linguagem (HABERMAS, 1997; MEDEIROS; MARQUES, 2003).

Diante disso, quanto à forma de tomar decisões por uma lente racionalista, o perito judicial em seu trabalho pode posicionar-se de forma instrumental, que Serva (1997) define como uma racionalidade baseada no cálculo, orientada para o alcance de metas técnicas ou de finalidades ligadas a interesses econômicos ou de poder social, por meio da maximização dos recursos disponíveis.

Por uma lente humanista, o perito pode direcionar sua razão e ações para o contexto substantivo proposto por Habermas, em que Serva (1997) define a ação substantiva como uma ação orientada para duas dimensões: i) uma individual, ligada à auto realização, concretização de potencialidades e satisfação, e ii) outra grupal, ligada ao entendimento, nas direções de responsabilidade e satisfação sociais.

$\mathrm{Na}$ vida em sociedade, embora ambas as racionalidades sejam complementares, por vezes ocorrem conflitos decisórios que demandam um posicionamento discricionário por parte dos peritos, a partir disso, o resultado pode culminar em posicionamentos mais sociais, voltados ao interesse coletivo, ou de outro lado levam a decisões de cunho mais utilitário e racional sob a ótica econômica individual.

Diante das duas racionalidades, considerando-se que o objeto da perícia é um guia para a prova pericial, sob a ótica positivista o perito parte geralmente do raciocínio indutivo e chega a verdade que se impõe à inteligência, por sua clareza e objetividade (NASCIMENTO, 1991). No entanto, sob a perspectiva de Habermas, espera-se que as ações dos peritos contadores sejam precedidas de ambas as racionalidades, de forma que sejam alcançados os fins contabilométricos necessários, contudo, em um ambiente de entendimento e consenso.

Todavia, essa expectativa de consenso é afetada pelo tensionamento entre ambas as racionalidades, pois as convicções e preferências pessoais podem tomar frente nas etapas do trabalho e impedir uma 
avaliação mais substantiva dos fenômenos, que resulte em entendimento e julgamento ético (CARDOSO; MULLER, 2018). Neste contexto, levanta-se a seguinte questão de pesquisa: que tipos de tensionamentos permeiam a tomada de decisão de peritos contadores? O estudo objetiva mensurar o nível das racionalidades substantiva e instrumental presente nas decisões de peritos contadores e verificar possíveis pontos de tensionamento.

Apoiado nas recomendações de Serva et al. (2015) para novos estudos sobre as racionalidades substantiva e instrumental, este estudo explora as lacunas de pesquisa evidenciadas nos trabalhos de (CAITANO, 2010; SILVA, 2011; SANTOS; SIQUEIRA, 2017, SANTOS; SERVA, 2013), que incentivam o aprofundamento em alguns processos organizacionais por meio de categorias de análise próprias.

Há relevância e necessidade de pesquisas sobre a atividade de perícia contábil no Brasil. O resultado da análise em 33 revistas entre 2006 a 2015 (SILVA et al., 2018) revela 24 artigos publicados que abordam a temática, o que corresponde a $0,43 \%$ do conteúdo publicado no período para as revistas analisadas. Concluise que esses trabalhos são poucos e concentrados em publicações de mestres e doutores (ANJOS et al., 2015; TAVEIRA et al., 2012). Além disso, as relações de colaboração existentes entre pesquisadores e instituições são fracas e apresentam pouca integração e coesão (SCHMITZ et al., 2013).

No campo profissional, houve um avanço após a criação do Cadastro Nacional de Peritos Contadores (Resolução CFC 1.502, 2016) e do Exame Nacional de Qualificação Técnica, ambos pelo Conselho Federal de Contabilidade. Por sua vez, a ciência precisa contribuir por meio da investigação e explicação dos problemas da área.

Quanto à prática, a investigação das dimensões racionais que afetam a tomada de decisão permite analisar possíveis inter-relações com as causas de problemas de ineficácia dos laudos periciais ligadas ao cumprimento de questões normativas (CESTARE; PELEIAS; ORNELAS, 2007), e o gap entre o produto do trabalho pericial e as reais necessidades e expectativas dos magistrados, de forma a se buscar avanços tanto na dimensão contabilométrica presente na sentença judicial, bem como o equilíbrio nas relações sociais do trabalho pericial.

Ademais, na esfera social este estudo estimula a reflexão acadêmica sobre possíveis diretrizes para subsidiar uma formação mais adequada de futuros peritos contadores, de forma a se atingir uma dimensão omni-social, bem como investigar fatores de assimetria entre o conteúdo de perícia contábil ensinado nas universidades e as demandas judiciais reais. Portanto, este estudo apresenta-se como um sinalizador para a melhoria das práticas de ensino, ao mesmo tempo que discute aspectos profissionais.

\section{Referencial Teórico}

\subsection{Contexto Histórico-Social da Perícia Contábil}

Apoiado no pensamento de Habermas, que analisa os indivíduos em uma relação sujeito-sujeito ao invés de sujeito-objeto, é possível situar a atividade de perícia contábil em um contexto em que os participantes do processo interagirão em uma relação dialógica de trabalho (FREITAG, 1995) que vai além das diretrizes legais e busca o entendimento recíproco (MEDEIROS; MARQUES, 2003).

Embora a atividade de perícia contábil seja regulada por normas emitidas pelo CFC, que constituem um padrão de regras e procedimentos técnico-científicos a serem observados pelo perito, é importante considerar que métodos, metodologias, normas e estruturas são convenções humanas que são legítimas em um dado momento do tempo e espaço, portanto, o indivíduo que adota por diretriz somente aspectos legais é incapaz de perceber o mundo vivido ao seu redor, torna-se objetificado e infértil na construção do conhecimento de sua área profissional, fica sujeito a uma relação monológica.

Sob a ótica substantiva, a consideração do aspecto histórico-social ajuda a formar o conjunto de informações e valores presentes na atuação do perito, além de considerar o mundo exterior que é uma realidade. Segundo Alberto (2000), o perito surgiu do primitivo direito romano e atuava com um árbitro, quando a decisão de uma questão dependia da apreciação técnica de um fato, o magistrado detinha a faculdade de deferir o juízo da causa a homens probos que melhor pudessem, por meio de seus conhecimentos técnicos, pronunciar-se sobre os fatos, portanto, essa pessoa se constituía em verdadeiro juiz e perito ao mesmo tempo.

Embora relatos apontem que a perícia tenha surgido antes da era cristã (ANJOS; LIMA; MARTINS, 2010; SÁ, 2011), em pleno século XXI estudos sobre perícia contábil são pouco difundidos, isso é um paradoxo em razão da importância da área. Uma possível justificativa similiar ao que ocorre no campo internacional, é que muitos trabalhos são de natureza técnica ou estão mais direcionados à Forensic Accounting, como ocorre nos Estados Unidos e Canadá (PELEIAS et al., 2011).

No Brasil, a partir do século XVII criou-se definitivamente a figura do perito como auxiliar da justiça, e do perito extrajudicial para defender as teses das partes envolvidas em demandas judiciais (FONSECA et al., 2000). Isso permitiu a especialidade do trabalho judicial, pois o perito, manus longa do juízo, contribui para que a decisão judicial seja tomada com o alcance de detalhes técnicos que não poderiam ser alcançados pelo conhecimento jurídico.

Atualmente, as convenções sociais do século XXI já não consideram o papel do perito tal qual foi no 
passado, quando era constituído um juiz temporário para questões específicas, mas, sua importância é de igual valor, pois sua opinião evoluiu para uma condição de prova formal quanto a fatos técnicos e sociais do mundo vivido. A condição de elemento de prova é assegurada pela legislação brasileira no artigo 464 do Código de Processo Civil (CPC, 2015), que define a prova pericial como um exame, vistoria ou avaliação, bem como conceitua o perito como a pessoa detentora de conhecimento técnico ou científico (Art. 156 do CPC, 2015).

Portanto, a atividade pericial contábil surge da necessidade de se obter uma análise crítica e pormenorizada em assuntos de natureza patrimonial em seus aspectos financeiro e econômico, por perito registrado no Conselho Regional de Contabilidade (CRC), que culmina com o laudo pericial lavrado (LEITÃO Jo. et al., 2012). Além disso, a perícia é uma expressão genérica que abriga diversos tipos de exames de natureza especializada, visando esclarecer determinado fato sob a ótica científica, inclusive os que servirão de base para a elucidação de situações de natureza criminal (LIMA; GONÇALVES, 2018).

A partir dessas considerações, Hoog (2008) define a perícia contábil como um serviço especializado, com bases científicas, contábeis, fiscais e societárias, que exige formação de nível superior e deslinda questões judiciais e extrajudiciais, portanto, é utilizada como elemento de prova pelos tribunais. Para corroborar, Sá (2011) explica que a função principal da perícia é servir de prova, esclarecendo o juiz sobre fatos que mereçam seu julgamento, objetivando situações ligadas ao patrimônio aziendal ou de pessoas. Neste sentido, ela produz efeitos que afetam a inteligência do juiz, que forma por meio do raciocínio nela desenvolvido, o juízo positivo ou negativo que servirão de base para a decisão judicial equilibrada (GRECO, 2004).

Apesar do cunho instrumental presente na definição de perícia contábil, a prova pericial não é reflexo unicamente de conhecimentos técnicos, mas também contempla o âmbito filosófico presente no perito, pois concede ao perito a sabedoria necessária, de forma a evitar efeitos destrutivos e desequilibrados na produção da prova pericial (HOOG, 2008).

Decorrente disso, Weber (1968) considera que o trabalho pericial sofre a influência dos valores e de afetos (CROZIER, 1981). Em consequência disso, é influenciado pela racionalidade instrumental (formal) e pela racionalidade substantiva (de valor), em que a primeira é determinada por uma expectativa de resultados ou fins calculados, enquanto a segunda abrange valores sociais mais amplos e reflete, além da acurácia fundamentada no cálculo e relação de custo benefício, aspectos subjetivos individuais do perito.

Na sequência, a Figura 1, adaptada de Serva (1997), mostra os elementos constitutivos da ação racional, segregados por tipo de ação racional substantiva e ação racional instrumental, e detalha a natureza dos pressupostos das ações, por meio das quais é possível predizer o comportamento em relação ao indivíduo tomador de decisão.

\section{Figura 1: Elementos constitutivos da ação racional}

\begin{tabular}{|c|c|c|}
\hline \multicolumn{3}{|r|}{ Ação Racional Instrumental } \\
\hline 1 & Cálculo & Projeção utilitária das consequências dos atos humanos \\
\hline 2 & Fins & Metas de natureza técnica, econômica ou política (aumento de poder) \\
\hline 3 & $\begin{array}{l}\text { Maximização dos } \\
\text { recursos }\end{array}$ & $\begin{array}{l}\text { Busca da eficiência e da eficácia máximas, sem questionamento ético, no tratamento de } \\
\text { recursos disponíveis, quer sejam humanos, materiais, financeiros, técnicos, energéticos } \\
\text { ou ainda, de tempo }\end{array}$ \\
\hline 4 & Exxito, resultados & $\begin{array}{l}\text { O alcance, em si mesmo, de padrões, níveis, estágios, situações, que são considerados } \\
\text { como vitoriosos face a processos competitivos numa sociedade capitalista }\end{array}$ \\
\hline 5 & Desempenho & Performance individual elevada na realização de atividades, centrada na utilidade \\
\hline 6 & Utilidade & Dimensão econômica considerada na base das interações como um valor generalizado \\
\hline 7 & Rentabilidade & Medida de retomo econômico dos êxitos e dos resultados esperados \\
\hline 8 & $\begin{array}{l}\text { Estratégia } \\
\text { interpessoal }\end{array}$ & $\begin{array}{l}\text { Aqui entendida como influência planejada sobre outrem, a partir da antecipação das } \\
\text { reações prováveis desse outrem a determinados estímulos e ações, visando atingir seus } \\
\text { pontos fracos }\end{array}$ \\
\hline \multicolumn{3}{|r|}{ Ação Racional Substantiva } \\
\hline 1 & Autorrealização & $\begin{array}{l}\text { Processos de concretização do potencial inato do indivíduo, complementados pela } \\
\text { satisfação }\end{array}$ \\
\hline 2 & Entendimento & $\begin{array}{l}\text { Ações pelas quais se estabelecem acordos e consensos racionais, mediadas pela } \\
\text { comunicação livre, e que coordenam atividades comuns sob a égide da responsabilidade } \\
\text { e satisfação sociais }\end{array}$ \\
\hline 3 & Julgamento ético & $\begin{array}{l}\text { Deliberação baseada em juízos de valor (bom, mau, verdadeiro, falso, certo, errado etc.), } \\
\text { que se processa através do debate racional sobre as pretensões de validez emitidas pelos } \\
\text { indivíduos nas interações }\end{array}$ \\
\hline 4 & Autenticidade & Integridade, honestidade e franqueza dos indivíduos nas interações \\
\hline 5 & $\begin{array}{l}\text { Valores } \\
\text { emancipatórios }\end{array}$ & $\begin{array}{l}\text { Aqui se destacam os valores de mudança e aperfeiçoamento do social nas direções do } \\
\text { bem-estar coletivo, da solidariedade, do respeito à individualidade, da liberdade e do } \\
\text { comprometimento, presentes nos indivíduos e no contexto normativo do grupo }\end{array}$ \\
\hline 6 & Autonomia & $\begin{array}{l}\text { Condição plena dos indivíduos para poderem agir e expressarem-se livremente nas } \\
\text { interaços }\end{array}$ \\
\hline
\end{tabular}

Fonte: Serva (1997). 
No contexto da Figura 1, Lima e Gonçalves (2018) sugerem que os peritos devem atuar em um nível de ponto de equilíbrio entre os tipos de racionalidade instrumental e substantiva e, dessa forma, a prova pericial poderia ser mais eficaz, à medida que o equilíbrio evitaria a apresentação de conteúdos e opiniões infra e/ou ultra petita, pautados nas relações humanas presentes nas demandas judiciais.

Portanto, os aspectos técnicos, teóricos, filosóficos e de valores presentes na ação do perito irão em certo grau afetar sua opinião sobre fatos em uma área desconhecida pelo julgador, e constituem a densidade e o poder de convencimento, em razão de ser produzida por um terceiro estranho ao processo, o que revela seu caráter de isenção quanto aos resultados (Art. 149 do CPC, 2015; NEVES, Jo.; CERQUEIRA; GOTTARDO, 2014).

\subsection{Perícia Contábil e Educação}

Ao adentrar no debate de questões ligadas ao ensino da disciplina de perícia contábil pelas instituições de ensino superior, busca-se tomar a razão como principal recurso para enfrentar adversidades e buscar alternativas para resolver problemas (HABERMAS, 1987). Nesta direção os saberes aprendidos sobre perícia contábil não devem ser orientados exclusivamente por interesses técnico instrumentais, mas por interesses práticos e emancipadores (MÜHL, 2011).

Nesta dimensão, Mühl (2011) explica que a racionalidade subjetiva sustenta-se no pressuposto de que o sujeito tem primazia sobre o objeto, assim, a racionalidade comunicativa se apresenta como uma alternativa crítica a uma concepção intuitiva e introspectiva ensinada sobre a perícia contábil. Ao comentar Habermas, Mühl (2016) enfatiza que o saber sustenta-se na concepção de que o mundo da vida é portador da verdade que, enquanto não colocada em questionamento, é absoluta e incondicionada, mas quando as relações são problematizadas os participantes assumem uma atitude reflexiva e desenvolvem seus argumentos para explicar e justificar, podem mudar a concepção de verdade sob uma perspectiva de intersubjetividade.

Neste cenário, o ensino da perícia contábil deve imergir em uma filosofia da consciência, de forma que o modelo sujeito-objeto ceda espaço para um agir comunicativo que tome por base a intersubjetividade ancorada na linguagem (HABERMAS, 2012).

A Resolução (CNE/CES 10/2004) aponta em seu artigo 4ํas condições mínimas que o curso de ciências contábeis deve fornecer para a formação do futuro profissional, de forma a direcioná-lo a uma visão sistêmica, interdisciplinar e com a aplicação adequada da legislação inerente às funções contábeis. Aquém das necessidades, tais condições deveriam também refletir a capacidade de interação com o mercado de trabalho atual, uma virtude que vai além da expertise técnica (CAMPOS; GOMES; LIMA JÚNIOR, 2015).

O risco que se apresenta neste ambiente de relevância técnica, é o surgimento de assimetrias entre as habilidades e competências adquiridas pelo discente no curso de ciências contábeis e àquelas requeridas pelo mercado de trabalho, o que coloca as instituições de ensino superior diante de um desafio de formar profissionais com equilíbrio entre habilidades técnicas e humanas. Esta inferência é corroborada por França e Barbosa (2015), que em seu estudo no Distrito Federal junto a concluintes da disciplina de perícia contábil, constataram um alto grau de desinformação em relação aos desafios e oportunidades do mercado da perícia contábil,

Além das diretrizes legais, no mundo vivido, Martins, Martins A. M. e Araújo (2017) apontam que as instituições de ensino reconhecem a absorção de conhecimentos na disciplina de perícia contábil, porém, de forma geral os alunos não sentem-se aptos para exercer tal função e apesar do domínio teórico e prático por parte dos docentes, não há metodologias de embasamento prático.

Para Conte e Habowski (2019), enfrentar a dissociação entre o mundo acadêmico e o realidade da vida requer a superação de orientações descoordenadas que alienam a formação e deve haver espaço para a (re)elaboração argumentativa do conhecimento frente aos meios tecnológicos, para iniciar um diálogo de mudança que corroa a instrumentalização técnica e de poder, por meio das relações sociais, da reflexão, do questionamento e do exercício da crítica.

Para trilhar esse caminho é imprescindível uma atitude de planejamento por parte das instituições de ensino, de forma a se alcançar um patamar de qualidade e eficácia esperado pela comunidade de negócios e pela profissão contábil (REZAEE; CRUMBLEY; ELMORE, 2004).

Todavia, o que se constata segundo Cruz (2017) e Peleias et al. (2011) são situações que mostram a carência de escolha de métodos eficazes no processo de ensino da disciplina de perícia contábil, prevalecendo a adoção de aulas expositivas como estratégia de ensino, em detrimento a utilização de métodos ativos, como os estudos de caso, a resolução de situações problema e os debates do mundo vivido.

Déficits no processo de ensino-aprendizagem poderão afetar a qualidade dos saberes necessários ao perito, que virão à tona na execução de seu trabalho e refletirão na sociedade, quer pelo aumento do volume de processos atrasados por conta de impugnações de laudos por erros ligados à falta de expertise, quer por prejuízos financeiros às partes processuais e à celeridade processual.

Ademais, a formação de um indivíduo incapaz de interagir socialmente, estimula um processo de comunicação deficiente entre o perito e o juízo ou com as partes processuais, e quando as últimas percebem "insuficiência" técnica ou substantiva da parte do perito, por exemplo, o perito não se mostra capaz de 
argumentar de forma convincente junto ao juízo, a parte que encontra-se em iminência de sucumbência processual, irá adotar todos os meios legais e uma forte argumentação para desqualificar o trabalho pericial.

Diante disso, é necessário uma discussão mais profunda e abrangente sobre o conteúdo do currículo da disciplina de perícia contábil, que precisa abranger a questão temporal para a ministração da disciplina, bem como a adoção de outras metodologias que possam apresentar aos discentes o "mundo real" da perícia, os riscos que irão enfrentar e os meios para que os futuros profissionais não fiquem expostos a situações constrangedoras.

Assim, embora devam caminhar juntas as racionalidades instrumental e a substantiva, suspeita-se, pelos motivos debatidos neste estudo, que a racionalidade instrumental impera na atividade de perícia contábil, pois é comum constatar na prática muitos problemas de consenso e, uma das formas de conciliar as divergências presentes nas teses judiciais é a racionalidade substantiva do perito, que por meio do equilíbrio oriundo dos valores e da comunicação de forma urbana, evita a desordem (PASSERI, 2003).

Para ilustrar tipos de interações negativas por parte dos peritos, mantendo-se o devido sigilo ético requerido, extraiu-se de processo judicial real, aqui com o codinome processo $\mathrm{X}$, a decisão do Juízo $\mathrm{Y}$, que assim proferiu sobre o profissional Z:

Considerando que o perito Z, mesmo após intimado (seq. WWW.W), não apresentou o laudo pericial em Juízo (seq. WWW.W) determino sua inabilitação para realizar outras perícias em processos judiciais pelo prazo de 2 anos (Art. 158, CPC), contados da data desta decisão. Promova a Secretaria a anotação da inabilitação no sistema NONONO.

Oficie-se ao órgão de classe do perito comunicando o teor desta decisão (Art. 158, CPC). Condeno o perito Z à devolução do valor já levantado (seq. WWW.W), com juros de mora e correção monetária pelo INPC a partir desta decisão.

Intime-se o perito $\mathrm{Z}$ do teor desta decisão. Juiz de Direito $(\mathrm{Y})$.

É comum também a inobservância da racionalidade substantiva em questões primárias, como no princípio da urbanidade que deve prevalecer na relação com o poder judiciário, o que pode ser constatado na descrição parcial de sentença $X$, que por ética, não é citada a fonte:

Desnecessário que a ofensa fosse praticada em detrimento de outro contador para a configuração do ilícito ético. O teor do dispositivo remete à imagem da classe profissional, devendo o perito zelar pelo prestígio e dignidade da mesma. Impossível sustentar que o uso de palavras agressivas seja o meio adequado para atacar uma decisão judicial, sobretudo por atuar como auxiliar do próprio juízo.

Em resumo, quando os cursos de ciências contábeis não oferecem a qualidade necessária no ensino da disciplina de perícia contábil há um prejuízo ao processo de institucionalização da ciência contábil e de sua técnica pericial como função de prova judicial, o que pode levar os magistrados a buscarem, quando possível, outros tipos de prova e, além disso, dificulta a entrada de novos peritos no mercado de trabalho (LEITÃO JÚNIOR et al., 2012).

Nesta direção, o ensino na universidade precisa promover a emancipação do sujeito, tornando-o capaz de vislumbrar um horizonte no qual possa participar ativamente na transformação da sociedade em que vive (MOREIRA; VIEIRA; SILVA, 2015). Esta responsabilidade também é dos profissionais peritos, que no mundo vivido precisam colocar em prática os pressupostos básicos da ação intersubjetiva proposta por Habermas e reaprender constantemente por meio de aprendizagens sociais (CONTE; HABOWSKI, 2019).

\subsection{Aspectos Profissionais da Perícia Contábil}

No mundo vivido, não obstante os interesses meramente econômicos que modificam a interação dos sujeitos com o mercado de trabalho e podem reduzir relações a apenas um contrato de natureza econômica, há de outro lado uma lente que analisa tais relações sob o enfoque do trabalho enquanto fenômeno emancipador do ser humano, por meio do qual se expressam suas vontades e se concretizam seus interesses.

Nesta linha, Habermas (1982) considera em sua teoria do conhecimento que os indivíduos são motivados por interesses, que são orientações básicas que precisam estar relacionadas à condições de reprodução e autoconstituição possíveis da espécie humana: o trabalho e a interação.

Assim, sobrejacente ao âmbito mercadológico, na relação profissional o homem deve ser compreendido como um ser histórico, construído por meio de suas relações com o mundo natural e social, em que a lógica desenvolvimentista precisa considerar o indivíduo e suas dimensões culturais e sociais.

A partir disso, Canário (2016) explica que a escolha entre o ter e o ser, pode representar o sentido e a natureza da vida humana, que pode estar refletida nos diferentes modos de articular a aprendizagem e 0 trabalho, bem como a redefinição das finalidades éticas da ação humana.

Para muitos os peritos são pensados como máquinas de fazer cálculos que atendem a requisitos estritamente técnicos, mas no mundo vivido não é exatamente assim. Em razão de que o trabalho pericial é 
um tipo de prova relacionado à solução de demandas judiciais, constantemente o perito está envolvido em conflitos de interesse (LIMA, 2013).

A permanência no mercado de trabalho não está ligada unicamente à acurácia do perito nos cálculos, mas também à sua capacidade de oferecer ajuda concreta para solucionar lides, como, por exemplo, em casos de avaliação de empresas, em que mais que cálculos os magistrados esperam que a metodologia adotada pelo perito tenha relevância científica ao ponto de ser acatada pelas partes. Na Figura 2 é possível visualizar o macro fluxo de produção da prova pericial, desde o pedido de provas pelo juízo ou pelas partes até a conclusão do trabalho.

Figura 2. Macroprocesso da Perícia Judicial.

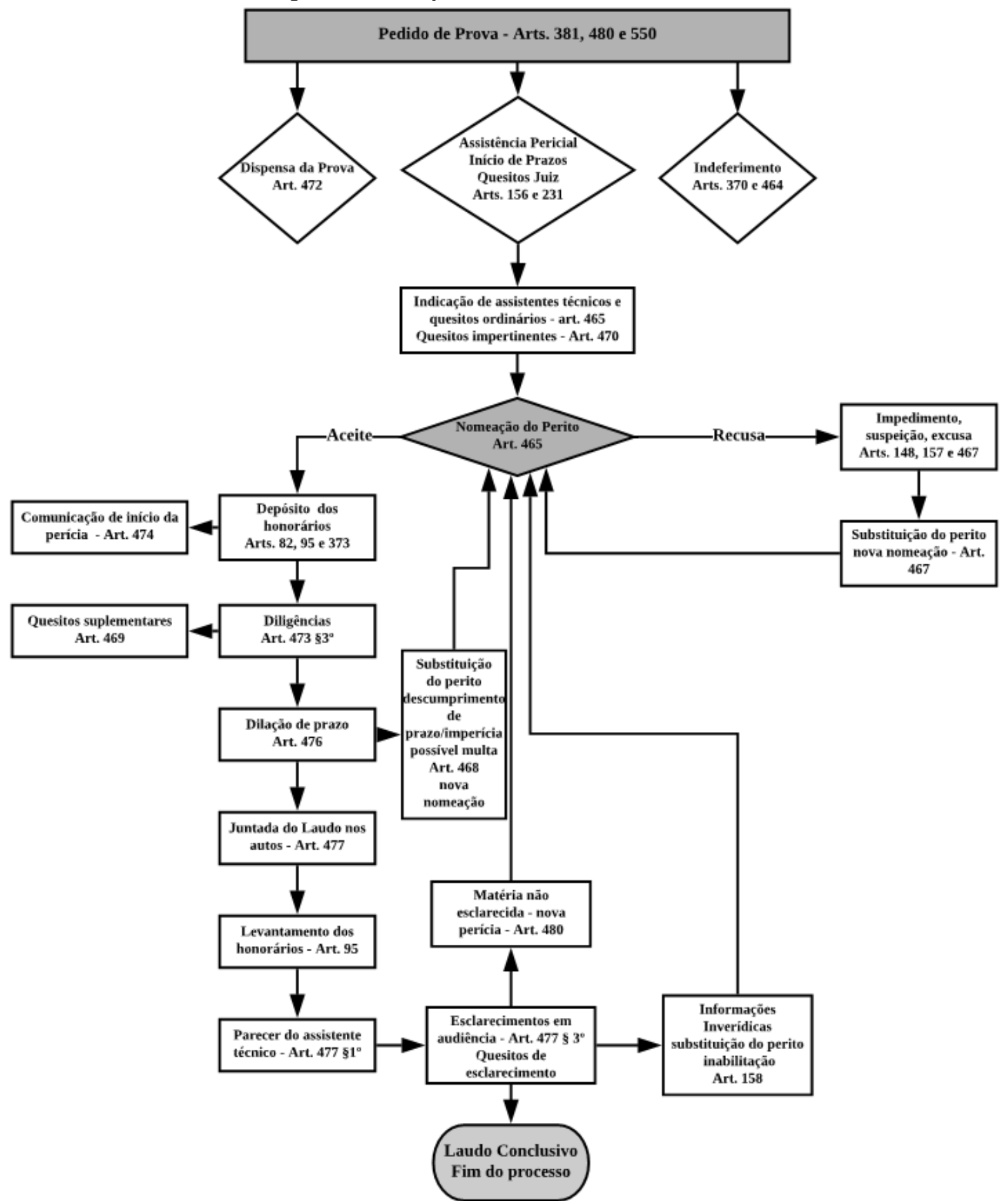

Fonte: Brasil - Lei Federal no 13.105, de 14 de março de 2015.

No Brasil, o mercado de trabalho do perito abrange as justiças federal e estadual, varas cíveis e criminais, de falência e concordata, família, precatórios, fazendas públicas, execuções fiscais e trabalhistas, além de empresas públicas e privadas (NEVES JÚNIOR; MELO, 2012). Mais recentemente, com o advento 
da Lei no 13.129 (2015) despontou a justiça arbitral.

Dado à discrição no âmbito jurídico, não há como precisar exatamente qual a extensão das oportunidades do trabalho pericial no Brasil, no entanto, um dos principais indicativos desse mercado está ligado ao volume de demandas judiciais.

A esse respeito, uma das fontes mais confiáveis enquanto proxie para mensurar o mercado do perito judicial, é o relatório Justiça em Números (CNJ, 2019), que mostra em unidade de milhões, o volume de ações judiciais que tramitam na estrutura da justiça brasileira.

O relatório Justiça em Números (CNJ, 2019) aponta que no ano de 2018 ingressaram no judiciário brasileiro um total de 28.052 .965 novos casos de litígio. Isso somado ao número de casos pendentes 78.691.031, equivale ao total de 106.743.996 casos de litígio.

Este alto volume de ações no Brasil é resultado de várias causas, como os problemas sistêmicos do poder judiciário, o comportamento oportunístico relacionado à cultura de judicialização e do próprio sistema legal code law do Brasil. Diante disso, acredita-se que há uma perspectiva de crescimento de oportunidades para o trabalho do perito contábil judicial.

A partir desses números é possível visualizar diversas avenidas profissionais para o perito contábil, que pode atuar na justiça federal, na justiça estadual, na justiça do trabalho, na justiça arbitral, ou ainda exercer a função de assistente técnico para as partes envolvidas no processo judicial, caso deseje seguir este caminho.

\section{Método e Procedimentos}

Este estudo é de natureza descritiva, exploratória e quali-quanti, sua população de pesquisa é composta de peritos contadores listados no (CNPC, 2019), que segundo a Coordenadoria de Registros do CFC, em 30/04/2020 lista o total de 4.491 peritos. Para alcançar uma amostra viável foram pesquisados peritos pertencentes às regiões sul, sudeste, norte e nordeste do Brasil, que totalizou 19 Estados da Federação e resultou em uma amostra de 2.727 peritos. Contudo, após o envio do questionário verificou-se baixa adesão à pesquisa e alto retorno de notificação de e-mails inexistentes, possivelmente não atualizados no site do CFC.

Dada à dificuldade de se coletar dados somente por meio dos cadastros do CNPC, foram incluídos dados de peritos relacionados nos sites dos tribunais de justiça dos estados e das associações de peritos e, com a adição de peritos da região sudeste e centro-oeste, alcançou-se o total de 181 respondentes. Após a exclusão de respondentes que não confirmaram a atuação na esfera judicial, restou uma amostra final de 170 respondentes. A busca em mais de uma fonte se justifica porque há peritos contadores que não estão inscritos no CNPC, mas podem constar em outros cadastros.

A lógica para a análise dos dados toma por base que os valores são princípios que orientam a ação em direção à realização de objetivos, considerados como metas desejáveis (SERVA, 1996). Por sua vez, o processo decisório é considerado como a determinação do que se deve fazer por meio da escolha consciente de uma alternativa de comportamento que vise à consecução de uma meta e/ou resolução de problemas (SANTOS; SERVA, 2013).

Considera-se, portanto, que a racionalidade instrumental baseia-se em recursos empregados para se alcançar um resultado, enquanto que a racionalidade substantiva é inerente ao indivíduo, à sua psique, que resultam num debate racional em que o julgamento ético é a pedra angular (SERVA, 1996; GUERREIRO RAMOS, 1981).

Para investigar a razão que suporta a decisão dos peritos contadores, este estudo apoia-se no quadro proposto por Serva (1996) com base em Guerreiro Ramos (1981), mostrado na Figura 1. A ideia é que as decisões são influenciadas por um processo de comunicação, próprio de uma interação que ocorre entre os indivíduos, portanto, uma ação construída de forma dialógica.

Diante disso, busca-se construir uma categoria de análise mais aderente ao trabalho pericial, que identifique com mais objetividade e clareza a presença dos conhecimentos substantivo e instrumental na tomada de decisão do perito contábil nas etapas da pesquisa judicial, à luz das diretrizes normativas que deve seguir.

Neste contexto, a Figura 3 elaborada com base em Serva (1997) apresenta as categorias analisadas neste estudo, inerentes às três fases do trabalho pericial representadas pelo planejamento, execução e final (conclusão), bem como seus elementos constitutivos e as tensões mais comuns observadas em trabalhos de campo.

A categoria adequação ao objetivo está relacionada ao tensionamento que pode ocorrer durante o trabalho pericial. Se em uma ponta, o objetivo da perícia contábil previsto na legislação contábil (NBC TP01, 2015) está ligado à produção de elementos de prova em conformidade com as normas jurídicas e profissionais, em outra ponta, os interesses distintos manifestados nas teses produzidas pelas partes, demandam cálculos específicos e buscam por meio da utilização de técnicas jurídicas, conduzir o perito a tomar posicionamento alinhado a seus interesses. 
Figura 3 - Categorias e dimensões das racionalidades substantiva e instrumental

\begin{tabular}{|c|c|c|c|c|}
\hline Fases da Perícia & Categorias & Tensão & $\begin{array}{l}\text { Racionalidade } \\
\text { Instrumental }\end{array}$ & $\begin{array}{l}\text { Racionalidade } \\
\text { Substantiva }\end{array}$ \\
\hline Planejamento & $\begin{array}{c}\text { Adequação ao } \\
\text { objetivo }\end{array}$ & \multirow{3}{*}{$\begin{array}{l}\text { Ausência de } \\
\text { consenso. } \\
\text { Pressão das } \\
\text { partes. } \\
\text { Preferências } \\
\text { pessoais. }\end{array}$} & \multirow{3}{*}{$\begin{array}{l}\text { Cálculo, Fins, } \\
\text { Maximização de } \\
\text { recursos, EExito e } \\
\text { resultados, } \\
\text { Desempenho, } \\
\text { Utilidade, } \\
\text { Rentabilidade, } \\
\text { Estratégia } \\
\text { interpessoal. }\end{array}$} & \multirow{3}{*}{$\begin{array}{l}\text { Autorrealização, } \\
\text { Entendimento, } \\
\text { Julgamento ético, } \\
\text { Autenticidade, Valores } \\
\text { emancipatórios, } \\
\text { Autonomia }\end{array}$} \\
\hline Execução & $\begin{array}{c}\text { Comunicação com as } \\
\text { partes }\end{array}$ & & & \\
\hline Final & Revisões e ajustes & & & \\
\hline
\end{tabular}

Fonte: Os autores, com base em Serva (1997)

Diante disso, se por um lado a norma requer uma estrita interpretação de fatos objetivos ligados à produção de provas justas e equilibradas, por outro lado, o perito judicial se vê diante de um embate doutrinário das partes que demandam por vezes a simulação de outras metodologias, ainda que as mesmas não representem o posicionamento oficial do perito.

Considerando-se a experiência vivenciada pela análise de laudos periciais, há peritos contadores que se mostram mais instrumentais, refutam a hipótese de realizar simulações à tese das partes e mantém o estrito rigor metodológico. Porém, há peritos contadores que entendem o trabalho pericial de forma mais substantiva e debatem com as partes questões técnicas. Em resumo, o resultado do trabalho pode mostrar apenas um número e/ou informação ou, em outra direção revelará as habilidade de um verdadeiro auxiliar da justiça (Lei no 13.105, 2015) cujo posicionamento levará a efetivo equilíbrio judicial.

Nesta direção, o perito contábil que age em interesse social vê o produto de seu trabalho como fonte de equilíbrio e justiça social, pois em uma sentença judicial, por exemplo, de natureza financeira, nem sempre a parte Ré sucumbe integralmente. Por outro lado, o perito que adota uma postura mais instrumental, pode ficar sujeito a refazer seu trabalho após decisões em instância superior, quer por revisão de metodologia ou simplesmente por imperícia.

Por sua vez, a categoria comunicação com as partes (autor e réu) representa um dos pontos nevrálgicos no trabalho pericial. Desde a fase de planejamento, na elaboração de honorários, apresentam-se pontos de distensão entre o perito e as partes, que podem estender-se na fase de execução da perícia para debates entre o perito e os assistentes técnicos das partes. A norma (NBC PP01, 2015) prescreve em seus itens 38, letra g, e 39, que o perito judicial deve ser receptivo a argumentos e críticas, ratificando ou retificando posicionamento anterior, bem como deve manter transparência e respeito recíproco junto ao perito assistente.

Embora a legislação faculte ao assistente técnico participar da perícia judicial, inclusive do planejamento e execução conjunta, é comum os peritos judiciais dispensarem a participação do assistente, pois, em certas ocasiões pode ocorrer a interferência no trabalho pericial, além de aumentar o tempo com reuniões e debates científicos prévios à entrega do laudo pericial. Neste ponto, a decisão discricionária do perito pode impactar na qualidade e acato do trabalho pericial, à medida que a discussão prévia mais ampla com os assistentes técnicos, pode aumentar o consenso em relação às conclusões do laudo pericial e reduzir o tensionamento.

$\mathrm{Na}$ fase final da perícia, ocorre a terceira categoria denominada revisões e ajustes, que está ligada aos quesitos de esclarecimento e possíveis pedidos de retificação/complementação do laudo. Nessa fase é comum as partes pedirem esclarecimentos que podem culminar eventualmente em situações em que o perito contábil precisará retificar ou refazer o laudo, o que pode ocasionar um tensionamento entre o mesmo e os patronos das partes.

Esses problemas podem ser resultado de falta de clareza e utilização de termos técnicos na redação do laudo, erro de cálculos, prestação de informações incorretas. No entanto, podem também ser motivados por mero comportamento protelatório das partes, que buscam postergar o trâmite processual por seus interesses mais diversos e/ou por não concordarem com a metodologia adotada pelo perito, neste caso, utilizam lícitos recursos jurídicos para pressionar o perito a mudar de opinião ou convencer o juízo sobre a ineficácia da metodologia adotada pelo perito.

\subsection{Instrumento da pesquisa}

Para a construção do instrumento, que convencionou-se chamar de Escala de Tomada de Decisão por Peritos Contadores (EDPC), levou-se em consideração o aspecto da tensão na tomada de decisão, considerada uma situação entre dois ou mais elementos que provocam nos indivíduos sensações como desconforto, indecisão e incômodo psicológico, que podem levar a manifestações individuais ou coletivas (SANTOS; SERVA, 2013).

Neste contexto, elaborou-se um instrumento estruturado, que além de 7 questões de ordem demográfica e profissionais (idade, sexo, escolaridade, declaração de atuação judicial, tempo de atuação, áreas de atuação e estado do registro originário do perito no CRC), apresenta outras 15 afirmativas, divididas 
em três grupos de 5 questões cada, que refletem respectivamente o planejamento da perícia, a execução e a fase final (Figura 3). A mensuração será realizada por uma escala do tipo Likert de 11 pontos, que variam de 0 a 10. As afirmativas do instrumento são mostradas no Apêndice A.

Inicialmente, foi realizado um pré-teste com 5 peritos com mais de 10 anos de experiência, a fim de se analisar a validade interna dos constructos. Suas opiniões foram tomadas como base para ajustes nos instrumentos que posteriormente foram submetidos ao teste Alpha de Cronbach, cujo resultado conjunto das categorias é 0,82 . Após os testes de validade interna, foram enviados formulários de pesquisa por e-mail, por meio do Google Forms ${ }^{\circledR}$, no período de 25/05/2019 à 30/06/2019.

\subsection{Modelo Econométrico}

Os dados obtidos foram tratados inicialmente no software Microsoft Exce ${ }^{\Theta}$, momento em que foram excluídas respostas de peritos que declararam não atuar na esfera judicial. Em seguida, as estatísticas descritivas foram calculadas por meio do Software SPSS, versão 22 e foi adotada a técnica de análise multicritério DP2 a fim de criar um ranking das respostas, transformadas em pontos para se conhecer a predominância das racionalidades substantiva e instrumental para cada uma das categorias de análise realizadas.

A técnica multicritério DP2, ou distância P2 consiste em um modelo matemático complexo (ZARZOSA; SOMARRIBA, 2013) cuja função é estimar indicadores de distância sintéticas e mensurar variáveis latentes (JARAMILLO, 2008). Umas das vantagens em utilizar esse método é que os pesos associados a cada variável são atribuídos de forma não arbitrária (CANAVIRI, 2016), além de que pertence ao grupo de métodos de mensuração originados de derivações axiomáticas, ou seja, cumpre uma série de requisitos necessários para alcançar o objetivo declarado conforme pode ser constatado nos estudos de (MARTÍN; FERNÁNDEZ; MARTÍN, J. A. R, 2018; ZARZOSA; SOMARRIBA, 2013).

Dentre os cerca de 11 requisitos cumpridos pelo modelo considerado robusto, estão: i) os critérios de existência e determinação (o indicador sintético P2 existe realmente e assume um valor específico, desde que exista variação em cada um dos componentes e que isso seja finito e não zero), ii) monotonia (o indicador sintético P2 responde positivamente a uma mudança positiva nas variáveis e negativamente a uma mudança negativa), iii) quantificação singular (a partir de um conjunto ordenado de indicadores simples, a função matemática que define o indicador sintético P2 produz um único resultado numérico), iv) Invariância (o indicador sintético é invariável à alterações na origem e/ou escala das medidas dos componentes. Um explicação mais detalhada de cada um dos 11 critérios pode ser encontrada em (ZARZOSA; SOMARRIBA, 2013).

A equação utilizada para calcular a distância DP2 foi modificada por Trapero (1977), é baseada na distância de Frechet, sendo utilizada como fator de ponderação das distâncias estimadas, ou seja, o coeficiente de determinação $\left(R^{2}\right)$ é escrito por meio da Equação 1:

$$
D P_{2}=\sum_{i=1}^{n}\left\{(d i / \sigma i)\left(1-R^{2} i, i-1, \ldots, 1\right)\right\}
$$

Na Equação 1 , em que $d i=d i\left(r^{*}\right)=X_{r-1} X_{*}$, com a base referência $X^{\star}=\left(X_{* 1}, X_{* 2}, \ldots, X_{*_{n}}\right), \boldsymbol{n}$ é o número de variáveis, $\boldsymbol{X}_{\boldsymbol{r} i}$ é o valor da variável $i, \boldsymbol{\sigma}_{\boldsymbol{i}}$ é o desvio padrão da variável $i, \boldsymbol{R}_{\boldsymbol{i}}^{2}, i-1, \ldots .1$ é o coeficiente de determinação na regressão de $X_{i}$ sobre $X_{i-1}, X_{i-2}, \ldots, X_{1}$, já incluído, em que $\boldsymbol{R}_{i}^{2}=10$.

Segundo Trapero (1977) o coeficiente de determinação, $i-1, \ldots .1$, mede a porcentagem de variação de cada variável explicada pela regressão linear estimada usando as variáveis precedentes, resultando em um número abstrato. Martín et al. (2018) explicam que o fator resultante da técnica utilizada por Trapero (1977) $\left(1-R^{2} i, i-1, \ldots, 1\right)$ evita a redundância e afasta informações já fornecidas por variáveis anteriores, portanto, expressa a parte da variância $X_{i}$, não explicada por $X_{i-1}, X_{i-2}, \ldots, X_{1}$ e a parte já explicada pelo indicador precedente é obtido pela multiplicação de cada indicador parcial pelo coeficiente de determinação correspondente $\boldsymbol{R}_{i}^{2}, i-1, \ldots .1$ (SANCHES; MARTOS, 2014).

Em resumo, após a coleta de dados e a transformação das respostas dos peritos em pontos $(0$ a 10$)$ é realizado um agrupamento em forma de uma matriz, em que os elementos das linhas são os peritos respondentes e os elementos das colunas são as variáveis do estudo, separadas segundo as três categorias de análise, que são a adequação ao objetivo, a comunicação com as partes e a revisões e ajustes (Figura 3).

Segundo Gorla, Hein e Silva (2018) a distância DP2 propõe a diferença entre o valor de um indicador e outro que é tomado como referência, o que ajuda a resolver o problema da heterogeneidade das unidades de medida. No presente estudo, tomou-se como referência a pontuação 10, que representa uma decisão totalmente instrumental por parte do perito.

\section{Apresentação e Discussão dos Resultados}

A apresentação dos resultados decorre de sua intepretação à luz das ideias de Habermas, que considera a racionalidade substantiva uma dimensão da razão que os indivíduos possuem para se chegar a 
consensos entre o plano das ideias e das ações, de forma que o diálogo seja a base para a construção da verdade que leva ao bem social coletivo.

Inicialmente, após o tratamento estatístico dos dados, a análise multicritério DP2 foi calculada com base na equação de Trapero (1977) e os resultados serão apresentados individualmente para cada uma das três categorias de análise.

Em relação aos dados demográficos da pesquisa, os homens representam a maioria dos respondentes, $80,6 \%$, quanto à idade $52,9 \%$ dos respondentes estão acima de 46 anos, seguida de $22,9 \%$ que situam-se entre 36 e 45 anos e $21,2 \%$ de respondentes que estão entre 26 e 35 anos. Quanto ao nível de escolaridade, $65,9 \%$ dos respondentes possuem especialização, $18,2 \%$ declararam ter mestrado e $4,1 \%$ possuem curso de doutorado.

Considerando-se o total dos peritos respondentes (170), 45,9\% atuam entre 0 e 5 anos, entre 6 a 10 anos o percentual é de $21,2 \%$ e acima de 30 anos de trabalho na área estão os peritos que formam o percentual de 1,8\%. Quanto à esfera de atuação, 92,9\% declararam atuar na justiça cível, seguida das varas da fazenda pública, $45,9 \%$, da justiça federal $42,9 \%$, da justiça trabalhista, $34,7 \%$ e das varas de conciliação e arbitragem, 9,4\%.

De forma a consolidar os resultados, a Figura 4 mostra os principais valores obtidos da estatística descritiva, como a média e o desvio padrão, assim como é possível visualizar a variável MDDP2 que representa a mediana da distância DP2 para cada categoria. A Figura 4 foi construída a partir de uma escala denominada intensidade da racionalidade, que possibilita situar a distância DP2 para as três categorias analisadas. Esta escala compreende uma análise que deve partir da pontuação 5 (equilíbrio nas racionalidades) em direção a cada um de seus extremos, considerando que 0 (zero) representa um indivíduo totalmente substantivo e 10 um indivíduo totalmente instrumental. O desvio padrão na Figura 4 mostra pouca variação, o que aponta que os peritos contadores não racionalizam de forma muito diferente quando tomam suas decisões, pois os valores não superam a $4 \%$.

Figura 4 - Categorias e dimensões das racionalidades substantiva e instrumental

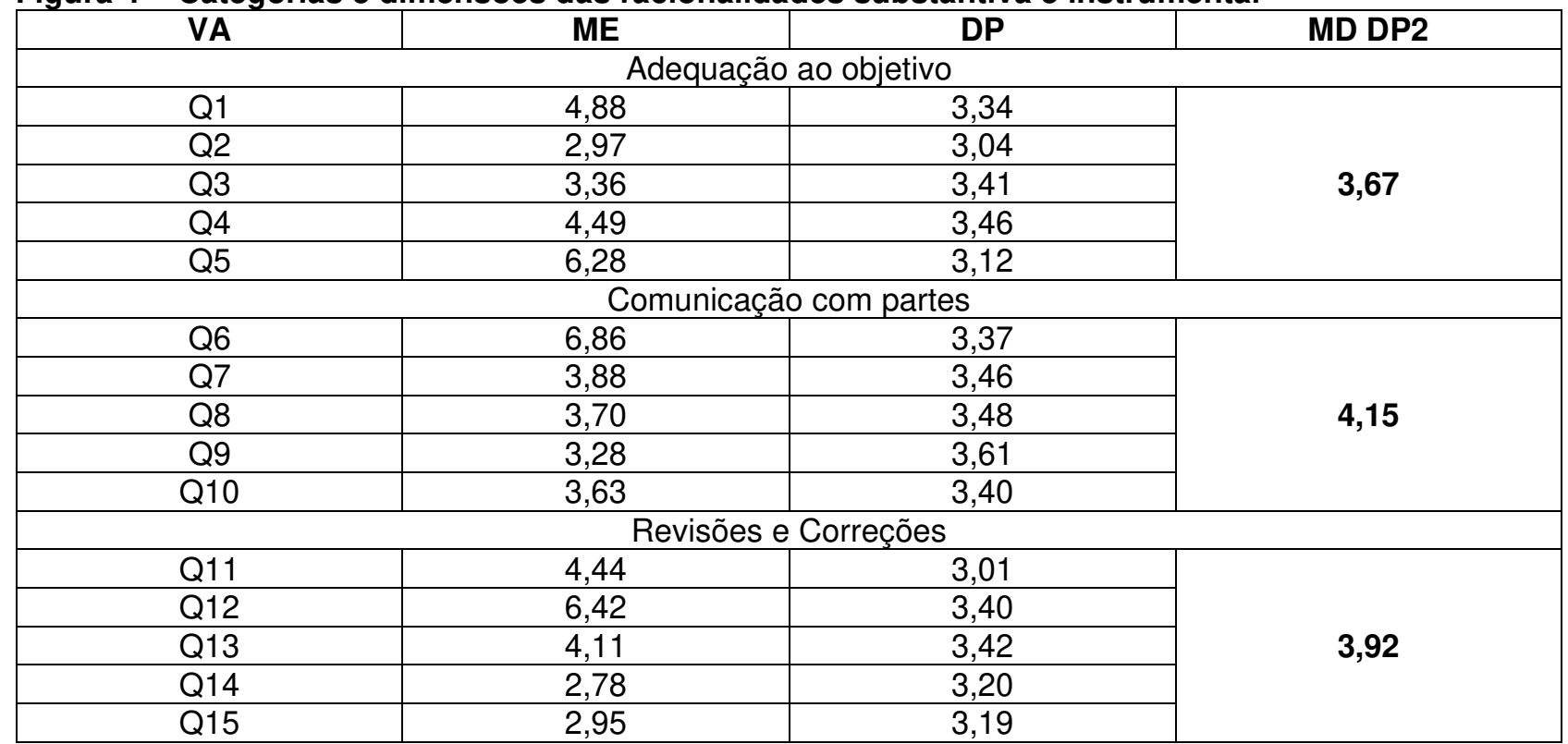

Legenda: $\mathrm{VA}=$ questões da pesquisa; $\mathrm{ME}=$ média; $\mathrm{DP}=$ desvio padrão; $\mathrm{MD} \mathrm{DP} 2=$ mediana obtida pela técnica $\mathrm{DP} 2$ para cada uma das categorias analisadas.

Fonte: os autores com base em Serva (1997)

O maior valor obtido para a informação da variável média ME é 6,86 proveniente da resposta à questão $n^{0}$ 6, cujo teor é o seguinte:

Q6. Na fase de execução da perícia, durante as diligências que realizo in loco, procuro não debater questões técnicas com os diligenciados, reservo-me a apresentar opinião apenas no Laudo Pericial.

A resposta dos peritos para a questão o 6 implica que há um distanciamento da razão substantiva nesta fase, porém, não representa adesão total à razão instrumental. Considerando-se que nesta fase existe uma oportunidade de se minerar informações importantes que poderão subsidiar o perito na elaboração de seu futuro laudo, é possível inferir que peritos focam mais em suas próprias capacidades técnicas, ao invés de buscar mais evidências junto às partes.

Esse debate na fase de execução poderia evitar retrabalho após a entrega do laudo, pois há evidências científicas de que advogados consideram que o laudo pericial não é suficientemente esclarecedor 
para tomarem suas conclusões, essa afirmação é motivada pelos termos técnicos utilizados pelos peritos, sem esclarecimento de seu significado (Prates et al., 2020; Silva et al. 2019).

Além disso, a pontuação obtida na questão № 14 que alcançou 2,78 pontos, corrobora a ideia de afastamento da razão substantiva na fase de execução da perícia, indicando que os peritos adotam uma postura substantiva quando são inquiridos a aumentar o tempo de trabalho e/ou redebater questões resolvidas em etapas anteriores.

Q14. Na fase de conclusão da perícia, quando me deparo com novos quesitos de esclarecimento em relação a fato já esclarecido, minha atitude é de ficar irritado e responder de forma mais breve possível.

Por sua vez, a mediana da distância DP2 que mais aproxima os peritos pesquisados de um comportamento substantivo está na categoria adequação ao objetivo, que mostra índice MD DP2 3,67. Nas cinco questões desta categoria, o perito precisou refletir situações em que seus objetivos econômicos e pessoais são confrontados com interesses distintos das partes.

Pode-se interpretar que, peritos quando lidam com fatores ligados ao objetivo da perícia, procuram levar em consideração o interesse das partes, conciliando quando possível, os interesses pessoais à causa da perícia. Por meio da resposta à questão $3 \mathrm{com}$ média 3,36 é possível visualizar este pressuposto:

Q3. Na fase de planejamento da perícia, quando me deparo com fatos relevantes para a solução de determinada demanda em relação ao objeto da perícia, busco não os informar no Laudo Pericial quando estão fora do escopo dos quesitos das partes e dos pontos controvertidos do Juízo.

Este índice apresentado na questão 3 é importante, pois uma postura diligente e dialética do perito com as partes, implica em dar e receber feedback (Moscovia, 1981). Isso pode levar ao entendimento e aceitação mútua, e por consequência diminuir o surgimento de controvérsias após a entrega do Laudo.

De forma geral, as pontuações apresentadas na Figura 4 para a distância DP2 mostram que os peritos contadores alinham-se perto da mediana, ou seja, suas respostas remetem ao equilíbrio entre as decisões instrumentais e substantivas (3,67 adequação ao objetivo; 4,15 comunicação com partes; 3,92 revisões e correções). Em linha com o estudo de Lima e Gonçalves (2018), os resultados também sinalizam uma aproximação dos peritos à racionalidade substantiva.

Não é possível afirmar que a racionalidade instrumental mostrada pela média das questões 5, 6 e 12 seja suficiente para evidenciar uma disputa de interesses entre os indivíduos ligados à um trabalho pericial. Contudo, Cardoso e Muller (2018) encontraram evidências de conflitos na área de licitação pública e seu estudo parece refletir uma tendência do judiciário brasileiro de tomar decisões mais proativas (overruling) no caso perícias de recuperação judicial, em que há decisões de pedido da perícia antes do deferimento da recuperação judicial, o que aproxima o fato ao modelo commom law (SIMON; VIEIRA, 2018).

Considerando que neste ponto do estudo é possível compreender um pouco mais sobre quais racionalidades permeiam a decisão dos peritos, adentra-se no debate dos tensionamentos que afetam a tomada de decisão de peritos contadores. Para rememorar, a Figura 3 relaciona três tipos de tensões: i) ausência de consenso; ii) pressão das partes e; iii) preferências pessoais.

Em todas as três categorias de análise foram elaboradas questões que buscaram captar os tensionamentos investigados. Primeiramente, em relação à ausência de consenso, a pontuação global para a variável MDDP2 nas três categorias analisadas é um sinalizador agregado de que os peritos contadores investigados buscam o equilíbrio em seus debates, vide a questão ํㅡㅇ.

Q8. Na fase de execução da perícia, após a instauração da perícia, procuro evitar a participação dos assistentes técnicos das partes, pois geralmente tenho que ajustar-me a um ou outro posicionamento prévio dos assistentes.

A média de pontuação para esta questão foi 3,70 e pode ser interpretado como distante de um posicionamento predominantemente instrumental dos peritos, isto mostra que eles estão abertos ao debate com os assistentes técnicos, e embora a pontuação não indique uma iniciativa ampla e pode estar relacionada também com a questão normativa, há um indicativo de propensão ao diálogo e, a partir dessa interação, é possível passar para o consenso proposto por Habermas. A respeito disso, acredita-se que a habilidade da comunicação pode ser desenvolvida na formação acadêmica dos contadores, no entanto, Paes, Kurtz e Tractenberg (2019) evidenciam que problemas ligados à metodologias de ensino, carga horária insuficiente e falta de aulas em formato de projetos para a prática de perícia, ainda são um entrave.

No que tange ao tensionamento pressão das partes, foi investigado nas questões relacionadas à prazo, posicionamentos técnicos e teses jurídicas distintas das diretrizes judiciais para o trabalho pericial. A resposta à questão no 9 com pontuação média 3,28 indica que os peritos contadores não evitam os embates, mesmo que isto represente uma oportunidade para que assistentes técnicos sondem a capacidade técnica do perito e explorem espaços para condicioná-lo a tomar direções metodológicas alinhadas a seus interesses. 
Q9. Na fase de execução da perícia, busco me abster de me reunir com os assistentes técnicos das partes para impedir que influenciem o trabalho pericial e prejudiquem o resultado da perícia.

Por último, as preferências pessoais podem gerar tensões importantes, ao passo que o perito ou a parte quando não estão dispostos a buscar consenso, prejudicam e dificultam o equilíbrio judicial, pois depositam nos autos um conteúdo em que os interesses, geralmente financeiros, são divergentes e podem resultar em recursos jurídicos para instâncias superiores.

Q12. Na fase de conclusão da perícia, ao realizar os esclarecimentos por escrito, quando percebo que as partes adotaram fortes argumentos cabíveis para desqualificar o Laudo Pericial, procuro justificar minha metodologia e não debater as teses contrárias.

Neste ponto, a resposta à questão no 12 mostra que os peritos judiciais tendem a desconsiderar a opinião das partes na etapa final da perícia, mesmo ao se depararem com argumentos pertinentes, ratificam sua metodologia. Esta posição instrumental com pontuação média 6,42, mostra baixa disposição à revisões quando os pedidos advém das partes e não do juízo, já que retificações oriundas de pedido judicial geralmente são acatadas segundo resposta à questão no 15 com pontuação média 2,95, mesmo quando não há remuneração para o perito.

Q15. Na fase de conclusão da perícia, se eu tiver que refazer ou complementar o Laudo Pericial por causa gerada pelo Juízo, somente realizo mediante complementação de honorários periciais.

A análise da questão $n^{0} 15$ sinaliza que em tensões relacionadas à preferências pessoais, os peritos consideram a entrega do laudo uma instância final em relação ao poder probante da perícia judicial, o que não pode ser tomado como verdade, pois, no pedido de esclarecimentos pelas partes a metodologia do perito pode ser questionada e inclusive desconsiderada pelo juízo.

À luz da teoria da ação comunicativa de Habermas, este estudo permite refletir que a perícia contábil, ainda que instrumental por questões normativas, é desenvolvida no mundo vivido com alguma ênfase substantiva, sem a qual os conflitos judiciais seriam mais difíceis de serem resolvidos, pois o ideal de razão científica que permeia o ocidente baseada nas concepções matemáticas (SILVA, 2010) não é suficiente para se alcançar os fins da atividade pericial, que é também enraizada nas questões sociais de cada tempo.

Portanto, pode ser proveitoso alinhar o ensino da disciplina de perícia judicial à moderna teoria do direito, cujas lógicas jurídicas têm em comum a preocupação com um tipo de racionalidade prática mais aproximada das técnicas da refutação, da controvérsia ou argumentação do que com à lógica formal (SILVA, 2010).

No tocante à questão de pesquisa que busca conhecer os tipos de tensionamentos que permeiam a tomada de decisão de peritos contadores, os resultados apresentados nesse estudo carecem de mais confirmações da literatura. Embora os resultados mostrem alguns pontos comuns nas decisões de peritos, há uma limitação ao tipo de pesquisa Survey, que geralmente não se aprofunda na realidade de cada sujeito pesquisado e trabalha com dados declarados pelos sujeitos da pesquisa.

\section{Considerações Finais}

Este estudo teve por objetivo mensurar o nível das racionalidades substantiva e instrumental presente nas decisões de peritos contadores e verificar possíveis pontos de tensionamento, sob a perspectiva da teoria da comunicativa de Habermas.

Os resultados mais relevantes apontam que: i) que os peritos contadores que atuam na esfera judicial buscam se posicionar na mediana entre as racionalidades substantiva e instrumental; ii) que os peritos contadores que atuam na esfera judicial tendem a debater aspectos metodológicos com as partes nas fases iniciais da perícia, diminuindo esta lógica na fase final.

A principal contribuição deste trabalho é a oferta de uma discussão científica mais profunda, que pode estimular universidades, estudantes, pesquisadores e profissionais a repensar o mundo do trabalho da perícia judicial contábil, a fim de transcender o racionalismo instrumental em direção a uma perspectiva mais ampla, em que o plano das ideias se concretize em forma de trabalho que leve consenso ao mundo vivido.

Um ponto específico de contribuição para a teoria é demonstrar sob uma lente humanista, que os estudos sobre perícia contábil ainda são concentrados em aspectos técnicos, o que pode ser visto em trabalhos como o de (FILARDO et al., 2018; SILVA et al., 2019; SOUSA, 2020) que exploraram questões relacionadas à qualidade do serviço, a percepção do usuário quanto aos laudos periciais e os aspectos legais, respectivamente. Embora esses estudos sejam relevantes para o conhecimento da área, é necessário também compreender como as relações humanas afetam a percepção de qualidade do trabalho pericial, pois o meio instrumental escolhido é resultado de expectativas comportamentais, e a partir disso, a avaliação do 
trabalho de um profissional perito que se relaciona com pessoas, não pode ficar adstrito somente ao plano técnico. Nesta direção, o trabalho de Prates et al. (2020) que analisou o trabalho de analistas periciais em contabilidade do Ministério Público, encontrou que as competências comportamentais foram consideradas mais importantes que as técnicas adotadas.

De uma perspectiva prática, este trabalho busca incentivar os profissionais peritos para um aprofundamento nas técnicas contábeis científicas adotadas nas perícias, pois, embora muitos trabalhos científicos apontem para uma boa aceitação dos laudos sob a ótica dos magistrados (MEDEIROS et al. 2018; ESCALFI; RIMÃO; BORÇATO, 2018; LIMA et al., 2020), não significa em absoluto a qualidade contábil dos trabalhos, pois a avaliação é de matéria em que os magistrados geralmente são leigos, por isso nomeiam peritos. Não pretende-se aqui colocar dúvidas sobre a capacidade dos magistrados em avaliar o trabalho do perito contábil, mas enfatizar que é relevante investigar a qualidade do laudo sob a perspectiva da ciência contábil, já que o laudo atende a fins jurídicos, mas é contábil.

Uma das limitações deste trabalho é em relação aos aspectos subjetivos nas questões pesquisadas, que podem levar os peritos a interpretar as categorias de resposta de forma diferente, por exemplo, o conceito de concordo totalmente pode representar uma intensidade diferente de concordância entre os pesquisados (KAHNEMAN; KRUEGER, 2006).

Para futuras pesquisas, recomenda-se aprofundar a análise do nível de impacto dos laudos periciais na decisão dos magistrados, pois embora algumas pesquisas tenham investigado este tema, é comum ocorrer o acatamento parcial das conclusões do laudo, o que não o inviabiliza, mas pode não representar 0 atendimento pleno do objetivo da perícia. Sugere-se também pesquisar a causa dos conflitos entre o perito e os demais sujeitos envolvidos, pois isto viabiliza a compreensão do mundo vivido e possibilita que universidades melhorem o currículo da disciplina de perícia contábil para adequá-lo às contingências práticas.

Por fim, analisar o currículo dos peritos contadores permite investigar pontos norteadores das racionalidades instrumental e substantiva, a fim de se conhecer as relações entre a formação intelectual dos peritos e o tipo de racionalidade que prepondera em seus trabalhos.

\section{Referências}

ALBERTO, V. L. P. Perícia contábil. 2 Ed. São Paulo: Atlas, 2000.

ANJOS, L. C. M.; FREIRE, R. S.; SALES, J. D. A.; FREITAS, A. R. F.; SILVA, D. J. C. A utilização do laudo pericial elaborado pelo perito contador: um estudo descritivo nas varas cíveis estaduais da cidade de Maceió-Alagoas. Revista de Contabilidade - UFBA, v. 4, n. 1, p. 23-35, 2010. Disponível em: https://portalseer.ufba.br/index.php/rcontabilidade/issue/view/523/showToc. Acesso em: 01 ago. 2019.

ANJOS, C. E. L.; MACÊDO, J. M. A.; PEDERNEIRAS, M. M. M.; SOARES, Y. M. A. Produção científica na área de perícia contábil: um estudo bibliométrico em periódicos nacionais. Revista de Contabilidade da UFBA, v. 9, n. 3, p. 48-63, 2015. Disponível em

https://portalseer.ufba.br/index.php/rcontabilidade/article/view/12966/10123.

BRASIL. Lei Federal no 13.105, de 16 de março de 2015. Código de Processo Civil, Brasília, DF, 16 mar. 2015. Disponível em: http://www.planalto.gov.br/ccivil_03/_ato2015-2018/2015/lei//13105.htm. Acesso em: 16 jul. 2019.

BRASIL. Lei no 13.129, de 26 de maio de 2015. Altera a Lei o 9.307, de 23 de setembro de 1996, e a Lei ํo 6.404, de 15 de dezembro de 1976, para ampliar o âmbito de aplicação da arbitragem e dispor sobre a escolha dos árbitros quando as partes recorrem a órgão arbitral..., 2015.

BRASIL. Resolução CNE/CES 10, de 16 de dezembro de 2004. Conselho Nacional de Educação, Câmara de Educação Superior. Institui as diretrizes curriculares nacionais para o Curso de Graduação em Ciências Contábeis, bacharelado, e dá outras providências, 2004. Disponível em http://portal.mec.gov.br/cne/arquivos/pdf/rces10_04.pdf

BRASIL. Justiça em Números 2019. Conselho Nacional de Justiça. Brasília: CNJ, 2019. Disponível em https://www.cnj.jus.br/wp-content/uploads/conteudo/arquivo/2019/08/justica_em_numeros20190919.pdf

CAITANO, D. A racionalidade substantiva na gestão organizacional: contribuição para consolidação de um campo de estudos. (Dissertação de mestrado). Universidade Federal de Santa Catarina. Florianópolis-SC, 2010. Disponível em: https://repositorio.ufsc.br/handle/123456789/93717. Acesso em: 31 jul. 2019.

CAMPOS, A. C.; GOMES, M.S.; LIMA Jo, G. F. A percepção dos concluintes e graduados do curso de Ciências Contábeis de uma IES da Paraíba sobre o mercado de trabalho na área de Perícia Contábil: um 
estudo comparativo. Revista Brasileira de Contabilidade - RBC, 214, p. 18-31, 2015. Disponível em: http://www.rbcdigital.org.br/index.php/rbc/article/view/1286. Acesso em: 13 mai. 2019.

CANÁRIO, R. Trabalho e formação de adultos: entre o ser o ter. Revista Contemporânea de Educação, v. 11, n. 22, p. 264-280, 2016. DOI: https://doi.org/10.20500/rce.v11i22.2700

CANAVIRI, J. A. Measuring the concept of "wellbeing": A first approach for Bolivia. International Journal of Wellbeing, v. 6, n. 1, p. 36-80, 2016. DOI: http://dx.doi.org/10.5502/ijw.v6i1.363

CARDOSO, V. V.; MULLER, A. D. Racionalidade substantiva e racionalidade instrumental em licitações públicas: ganhos e perdas para a seleção da proposta mais vantajosa. Anais... I Simpósio LatinoAmericano de Estudos de Desenvolvimento Regional, 1 - UNIJUÍ, RS, 2018. Disponível em: https://publicacoeseventos.unijui.edu.br/index.php/slaedr/article/download/10550/9229. Acesso em: 12 jun. 2019.

CESTARE, T. B.; PELEIAS, I. R.; ORNELAS, M. M. G. O laudo pericial contábil e sua adequação às normas do Conselho Federal de Contabilidade e à Doutrina: um estudo exploratório. Revista de Contabilidade do Mestrado em Ciências Contábeis da UERJ, v. 12, n. 1, p. 1-14, 2007. DOI: https://doi.org/10.12979/rcmccuerj.v12i1.5568

CONSELHO FEDERAL DE CONTABILIDADE. Norma Brasileira de Contabilidade - NBC PP 01, de 27 Fevereiro de 2015. Disponível em: http://www1.cfc.org.br/sisweb/sre/detalhes_sre.aspx?Codigo=2015/NBCPP01. Acesso em: 27 abr. 2019.

CONSELHO FEDERAL DE CONTABILIDADE. Norma Brasileira de Contabilidade - NBC TP 01, de 19 de Março de 2015. Disponível em:

http://www1.cfc.org.br/sisweb/sre/detalhes_sre.aspx?Codigo=2015/NBCTP01. Acesso em: 27 abr. 2019.

CONSELHO FEDERAL DE CONTABILIDADE. Resolução CFC no 1.502, de 19 de Fevereiro de 2016. Dispõe sobre o Cadastro Nacional de Peritos Contábeis (CNPC) do Conselho Federal de Contabilidade (CFC) e dá outras providências. Disponível em:

http://www2.cfc.org.br/sisweb/sre/detalhes_sre.aspx?Codigo=2016/001502\&arquivo=Res_1502.doc

CONTE, E.; HABOWSKI, A. C. Formação de profissionais da educação: o agir comunicativo na educação como dispositivo e autoridade epistêmica à práxis tecnológica. Educ. Soc., v. 40, p. 1-16, 2019. DOI: http://dx.doi.org/10.1590/es0101-73302019193424

CROZIER, M. O fenômeno burocrático. Brasília: Editora Universidade de Brasília, 1981.

CRUZ, M. A. O. O ensino da perícia em cursos de ciências contábeis de instituições de ensino superior da região norte do Brasil. (Dissertação de mestrado). Programa de Pós-

Graduação em Ciências Contábeis - UNISINOS, São Leopoldo-RS, Brasil, 2017. Disponível em: http://www.repositorio.jesuita.org.br/handle/UNISINOS/6971. Acesso em: 23 abr. 2019.

ESCALFI, C. A; ROMÃO, G. O.; BORÇATO, E. C. Qualidade e relevância do laudo da perícia contábil judicial: um estudo de caso à luz da teoria das expectativas. Revista Ciências Empresariais - UNIPAR, v. 19, n. 1, p. 141-160, jan./jun. 2018. DOI: https://doi.org/10.25110/receu.v19i1.6719

FILARDO, D. P.; TAVEIRA, L. D. B.; PENHA, R. S.; MARTINS, A. M.; MARTINS, J. D. M. A contribuição do parecer pericial contábil nos processos de investigação. Revista de Administração e Contabilidade RAC, v. 5, n. 9, p. 146-159, 2018. Disponível em:

http://www.revistasfap.com/ojs3/index.php/rac/article/view/195/188. Acesso em: 27 ago. 2019.

FONSECA, A. A. S. et al. A perícia contábil. Revista Brasileira de Contabilidade - RBC, Brasília, v. 29, n. 123, p. 36-43, 2000.

FRANÇA, J. A.; BARBOSA, A. B. O ensino da perícia contábil em Brasília: percepções dos estudantes do curso de Ciências Contábeis. Revista Catarinense da Ciência Contábil, v. 14, n. 43, p. 63-73, 2015. DOI: http://dx.doi.org/10.16930/2237-7662/rccc.v14n43p63-73

FREITAG, B. Habermas e a teoria da modernidade. Caderno CRH - UFBA, v. 22, p. 138-163, 1995. DOI: http://dx.doi.org/10.9771/ccrh.v8i22.18781 
GORLA, M. C.; HEIN, M.; SILVA, J. C. Efeito Moderador de Fatores Macroambientais na Relação entre a Estrutura de Capital e o Desempenho Econômico de Empresas dos Países que compõem o G20. Anais... XVIII USP International Conference in Accounting, São Paulo, 2018.

GRECO, L. O conceito de prova. Revista da Faculdade de Direito de Campos, v. 4, p. 213-269, 2004. Disponível em http://fdc.br/Arquivos/Mestrado/Revistas/Revista04e05/Docente/13.pdf. Acesso em: 6 ago. 2019.

GUERREIRO RAMOS, A. A nova ciência das organizações: uma reconceituação da riqueza das nações. Rio de Janeiro: FGV, 1981.

HABERMAS, J. Conhecimento e Interesse. Rio de Janeiro: Zahar, 1982.

HABERMAS, J. Teoría de la acción comunicativa I: racionalidad de la acción y racionalización social. Madrid: Taurus, 1987.

HABERMAS, J. Teoria de la acción educativa: complementos y estudios previos. Madrid: Catedra, 1997.

HABERMAS, J. Teoria do agir comunicativo: sobre a crítica da razão funcionalista. São Paulo: WMF Martins Fontes. v. 2, 2012.

HOOG, W. A. Z. Prova pericial contábil: aspectos práticos \& fundamentais. 5.ed. Curitiba: Juruá, 2008.

JARAMILLO, L. A. E. Indicadores ambientales sintéticos: Una aproximación conceptual

desde la estadística multivariante. Gestión y ambiente, v. 11, n. 1, p. 121-140, 2008. DOI: 10.15446/ga

KAHNEMAN, D.; KRUEGER, A. B. Developments in the measurement of subjective well-being. Journal of Economics Perspectives, v. 20, n. 1, p. 3-24, 2006. DOI:10.1257/089533006776526030

LEITÃO Jo., L. R. D.; SLOMSK, V. G.; PELEIAS, I. R.; MENDONÇA, J. F. Relevância do laudo pericial contábil na tomada de decisão judicial: percepção de um juiz. Revista de Informação Contábil, v. 6, n. 2, p. 21-39, 2012. Disponível em: https://periodicos.ufpe.br/revistas/ricontabeis/article/view/7952. Acesso: 6 mai. 2019.

LIMA, J. S. O mercado de trabalho da perícia contábil. RRCF, v. 4, n. 1, p. 43-62, 2013. Disponível em: http://institutoateneu.com.br/ojs/index.php/RRCF/article/view/53/67. Acesso em: 16 jul. 2019.

LIMA, S. L. S.; FRAZÃO, D. M.; BARROS, R. M. J. B.; I. B. SOUZA, I. B. Perícia Contábil: as possíveis melhorias para o laudo pericial nos processos trabalhistas. Revista de Auditoria, Governança e Contabilidade, v. 8, n. 34, p. 15-31, 2020. Disponível em: http://fucamp.edu.br/editora/index.php/ragc/article/view/2028/1262\#

LIMA, R. S.; GONÇALVES, A. O. Racionalidade substantiva em unidades de perícia criminal contábil financeira.In: Congresso ANPCONT, 2018. Anais..., João Pessoa, 2018. Disponível em http://anpcont.org.br/pdf/2018_CPT166.pdf

MARTÍN, J. M. M.; FERNÁNDEZ, J. A. S.; MARTÍN, J. A. R. Comprehensive evaluation of the tourism seasonality using a synthetic DP2 indicator. Tourism Geographies, v. 21, n. 2, p. 1-22, 2018. DOI: https://doi.org/10.1080/14616688.2018.1505943

MARTINS, J. D. M.; MARTINS A. M.; ARAÚJO, A. O. A percepção dos discentes do curso de ciências contábeis quanto às habilidades e competências desenvolvidas na disciplina de perícia contábil. Reunir, $v$. 7, n. 2, p. 67-84, 2017. DOI: https://doi.org/10.18696/reunir.v7i2.559

MEDEIROS, A. M. S.; MARQUES, M. A. R. B. Habermas e a teoria do conhecimento. ETD - Educação Temática Digital, v. 5, n. 1, p. 1-24, 2003. Disponível em: https://nbn-resolving.org/urn:nbn:de:0168-ssoar104033. Acesso em: 27 ago. 2019.

MEDEIROS, J. T.; MELO, C. M. M. D.; LIMA, D. H. S.; BORGES, E. F. Determinantes da qualidade do trabalho pericial contábil nas varas cíveis da comarca de Natal-RN. Ambiente Contábil, v. 10, n. 1, p. 347370, 2018. DOI: https://doi.org/10.21680/2176-9036.2018v10n1ID11478 
MOREIRA, J. A. P.; VIEIRA, M. G.; SILVA, C. G. Entre a teoria, a prática e a tecnologia: relação entre o saber teórico e o saber prático no contexto da formação contábil e o pensamento de Jüngen Habermas. Brazilian Business Review, v. 12, n. 4, p. 130-148, 2015. DOI: https://doi.org/10.15728/bbr.2015.12.4.6

MOSCOVIA, F. Competência interpessoal no desenvolvimento de gerentes. Revista de administração de empresas, v.21, n.2, p.17-25, 1981. DOI: http://dx.doi.org/10.1590/S0034-75901981000200002

MÜHL, E. H. Habermas e a educação: racionalidade comunicativa, diagnóstico crítico e emancipação. Educ. Soc., v. 32, n. 117, p. 1035-1050, 2011. DOI: https://doi.org/10.1590/S0101-73302011000400008

MÜHL, E. H. Mundo da vida e educação: racionalidade e normatividade. Filosofia e Educação (RFE), v. 8, n. 2, p. 97-120, 2016. DOI: https://doi.org/10.20396/rfe.v8i2.8646391

NASCIMENTO, E. D. Lógica aplicada à advocacia: técnica de persuasão. 4. ed. rev. e ampl. São Paulo: Saraiva. 1991.

NEVES JÚNIOR, I. J.; CERQUEIRA, J. G. M.; GOTTARDO, M. S. P. Perícia contábil judicial: a relevância e a qualidade do laudo pericial contábil na visão dos magistrados do Estado do Rio de Janeiro. Pensar Contábil, v. 16, n. 59, p. 49-57, 2014. Disponível em: http://www.atena.org.br/revista/ojs-2.2.306/index.php/pensarcontabil/article/view/2047.

NEVES JÚNIOR, I. J.; MELO, W. M. Perito contábil judicial: um estudo exploratório sobre a inserção do perito contador no mercado de trabalho. Revista Brasileira de Contabilidade - RBC, n. 185, p .55-69, 2012. Disponível em: http://rbc.cfc.org.br/index.php/rbc/article/view/913

OLIVEIRA, E. R.; ROJAS, F. P. G; NUNES, A. G. F. A importância do parecer técnico-contábil elaborado pelos peritos-contadores assistentes como ferramenta de auxílio na tomada de decisão nos processos judiciais em trâmite nas varas cíveis da comarca de Londrina e região. Revista Brasileira de Contabilidade - RBC, n. 223, p. 10-21, 2017. Disponível em: http://www.rbcdigital.org.br/index.php/rbc/article/view/1505. Acesso em: 1 ago. 2019.

ORNELAS, M. M. G. Perícia Contábil. 5. Ed. São Paulo: Atlas, 2011.

PAES, A. L.S.; KURTZ, R. G. M.; TRACTENBERG, L. E. F. Desafios à Formação e Inserção Profissional de Peritos Contadores do Estado do RJ. In: Congresso de Administração e Contabilidade - AdCont 2019, 10., Anais... Rio de Janeiro, 2019.

PASSERI, E. L. A racionalidade substantiva na gestão empresarial. Revista CADE, Rio de Janeiro, p. 4653, 2003.

PELEIAS, I. R.; ORNELAS, M. M. G.; HENRIQUE, M. R.; WEFFORT, E. F. J. Perícia Contábil: análise das condições de ensino em cursos de ciências contábeis da região metropolitana de São Paulo. Educação em Revista, v. 274, n. 3, p. 79-108, 2011. DOI: https://doi.org/10.1590/S0102-46982011000300005

PRATES, A.; SALLABERRY, J. D.; FLACH, L.; PELEIAS, I. R.; SOUZA, R. B. L. Mapeamento de competências: necessidades de aprimoramento de analistas periciais em contabilidade do Ministério Público Federal. Revista Ambiente Contábil, v. 12, n. 1, p. 215-233, 2020. DOI: http://www.atena.org.br/revista/ojs-2.2.3-06/index.php/Ambiente

REZAEE, Z.; CRUMBLEY, D. L.; ELMORE, R. C. Forensic accounting education: a survey of academicians and practitioners. In: SSRN, 2004. Disponível em:

https://papers.ssrn.com/sol3/papers.cfm?abstract_id=518263. Acesso em: 18 jul. 2019.

SÁ, A. L. Perícia contábil. 10. ed. São Paulo: Atlas, 2011.

SANCHEZ, M. A.; MARTOS, M. J. A progressive approach to the measurement of regional performance in the European Union. Journal for a Progressive Economy, n. 3, p. 62-65, 2014.

SANTOS, L. S.; SERVA M. A tensão entre a racionalidade substantiva e a racionalidade instrumental na gestão pública: novos caminhos de um campo de estudo. In: Encontro da ANPAD, ENANPAD, 37, Anais... Rio de Janeiro, 2013.

SANTOS, M. P.; TAVEIRA, L. D. B.; PENHA, R. S. Características para a escolha e manutenção do perito 
contador sob a ótica dos usuários da informação do TJRN. Revista de Auditoria, Governança e Contabilidade - RAGC, v. 5, n. 21, p. 73-86, 2017. Disponível em http://www.fucamp.edu.br/editora/index.php/ragc/article/view/1107

SANTOS, V.; CUNHA, P. R.; TANQUELLA, M.; VALENTIM, I. Ruídos no processo de comunicação de perícias contábeis: um estudo na região do Alto Vale do Itajaí - SC. Sociedade, Contabilidade e Gestão, v. 8, n. 3, p. 55-72, 2013. Disponível em: http://www.atena.org.br/revista/ojs-2.2.306/index.php/ufrj/article/view/1938/1772. Acesso em: 27 abr. 2020,

SERVA, M. R. O. Racionalidade e organizações: o fenômeno das organizações substantivas. 633 f. Tese (Doutorado em Administração) - Fundação Getúlio Vargas. São Paulo: EAESP/FGV, 1996.

SERVA, M. R. O. A racionalidade substantiva demonstrada na prática administrativa. Revista de Administração de Empresas - RAE, v. 37, n. 2, p. 18-30, 1997. DOI:http://dx.doi.org/10.1590/S003475901997000200003

SERVA, M. R. O.; CAITANO, D.; SANTOS, L.; SIQUEIRA, G. A análise da racionalidade nas organizações um balanço do desenvolvimento de um campo de estudos no Brasil. Cadernos EBAPE.BR, v. 13, n. 13, p. 414-437, 2015. DOI: http://dx.doi.org/10.1590/1679-39511634

SCHMITZ, T.; SANTOS, V.; DALLABONA, L. F.; TRUPPEL, E. K.; TRUPPEL, L. Perícia contábil: análise bibliométrica e sociométrica em periódicos e congressos nacionais no período de 2007 a 2011. Revista Catarinense da Ciência Contábil, v. 12, n. 37, p. 64-79, 2013. DOI: http://dx.doi.org/10.16930/22377662/rccc.v12n37p. 64-79

SIQUEIRA, G. Tensão entre as racionalidades substantiva e instrumental: estudo de caso em uma ecovila no sul da Bahia. Cadernos EBAPE.BR - FGV, v. 15, n. , p. 768-782. DOI: http://dx.doi.org/10.1590/1679395155014

SILVA, B. B.; OLIVEIRA, J. G.; MOREIRA, W. S.; SOEIRO, T. M.; ARAÚJO, J. G. N. Produção acadêmica sobre perícia contábil nos periódicos nacionais de contabilidade: uma análise do último decênio. Revista de Contabilidade da UFBA, v. 12, n. 2, p. 98-114, 2018. Disponível em:

https://portalseer.ufba.br/index.php/rcontabilidade/article/view/21961/16069.

SILVA, G. B. L.; FREITAS, P. C.; ARAÚJO, J. G. N; SOEIRO, T. M. A percepção dos usuários sobre o laudo pericial e parecer técnico contábil. Práticas em Contabilidade e Gestão, v. 7, n. 4, p. 1-23, 2019. DOI: http://dx.doi.org/10.5935/2319-0485/praticas.v7n4e12790

SILVA, C. M. C. Racionalidade jurídica e direito: um pressuposto para estudar o processo civil contemporâneo sob a égide do formalismo-valorativo. Revista Eletrônica do Direito Processual, v. 6, n. 6, p. 184-221, 2010. Disponível em: https://www.e-publicacoes.uerj.br/index.php/redp/article/view/21572. Acesso em: 31 jul. 2019.

SILVA, M. Racionalidade substantiva no processo decisório: um estudo em instituições que lidam com o tratamento oncológico infanto-juvenil na cidade de Natal-RN. Revista de Administração Pública, v. 45, n. 5, p. 1327-1361, 2011. DOI: https://doi.org/10.1590/S0034-76122011000500005.

SIMON, C. M. S.; VIEIRA, L. K. O deferimento da perícia prévia contábil na recuperação judicial: uma aproximação ao common low. Revista de Direito da Empresa e dos Negócios, v. 2, n. 2, 2018. Disponível em: http://revistas.unisinos.br/index.php/rden/article/view/18237.

SOUSA, F. J. V. Perícia Contábil: a Atividade Pericial no Código de Processo Civil e no Código de Processo Penal - Aproximações e Distanciamentos. Pensar Contábil, Encarte Especial, parte da Edição 76, 2020. Conselho Regional de Contabilidade, Rio de Janeiro.

TAVEIRA, L. D. B.; CAMARA, R. P. B.; MEDEIROS, A. W.; MARTINS, J. D. M. Uma análise bibliométrica dos artigos científicos em perícia contábil publicados entre os anos de 1999 a 2012. RCMCC - UERJ, v. 18, n. 2, p. 49-64, 2012. DOI: https://doi.org/10.12979/7264.

TRAPERO, J. B. P. (1977). Problemas de la medición del bienestar y conceptos afines: una aplicación al caso español. INE, Madrid, 1977

WEBER, M. Economy and society. New York, Bedminster Press, v. 1, 1968. 
ZARZOSA, P.; SOMARRIBA, N. An assessment of social welfare in Spain: Territorial analysis using a synthetic welfare indicator. Social Indicators Research, n. 111, p. 1-23, 2013. DOI:

https://doi.org/10.1007/s11205-012-0005-0

\section{NOTAS}

\section{AGRADECIMENTOS}

Aos profissionais peritos contadores que cordialmente contribuíram na fase de validação do instrumento de pesquisa e participação como respondentes neste estudo.

\section{CONTRIBUIÇÃO DE AUTORIA}

Concepção e elaboração do manuscrito: A. C. Santos

Coleta de dados: A. C. Santos

Análise de dados: A. C. Santos, N. Hein

Discussão dos resultados: A. C. Santos, N. Hein

Revisão e aprovação: A. C. Santos, N. Hein

\section{CONJUNTO DE DADOS DE PESQUISA}

O conjunto de dados que dá suporte aos resultados deste estudo não está disponível publicamente.

\section{FINANCIAMENTO}

Não se aplica.

\section{CONSENTIMENTO DE USO DE IMAGEM}

Não se aplica.

\section{APROVAÇÃO DE COMITÊ DE ÉTICA EM PESQUISA \\ Não se aplica.}

\section{CONFLITO DE INTERESSES}

Não se aplica.

\section{LICENÇA DE USO}

Os Direitos Autorais para artigos publicados neste periódico são do autor, com direitos de primeira publicação para a Revista. Em virtude de aparecerem nesta Revista de acesso público, os artigos são de uso gratuito, com atribuições próprias, em aplicações educacionais, de exercício profissional e para gestão pública. A Revista adotou a licença Creative Commons Atribuição 4.0 Internacional - CC BY NC ND. Esta licença permite acessar, baixar (download), copiar, imprimir, compartilhar, reutilizar e distribuir os artigos desde que com a citação da fonte, atribuindo os devidos créditos de autoria. Nesses casos, nenhuma permissão é necessária por parte dos autores ou dos editores. Autores têm autorização para assumir contratos adicionais separadamente, para distribuição não-exclusiva da versão do trabalho publicada nesta revista (ex.: publicar em repositório institucional ou um capítulo de livro).

\section{PUBLISHER}

Universidade Federal de Santa Catarina. Curso de Ciências Contábeis e Programa de Pós-graduação em Contabilidade. Publicação no Portal de Periódicos UFSC. As ideias expressadas neste artigo são de responsabilidade de seus autores, não representando, necessariamente, a opinião dos editores ou da universidade.

\section{EDITORES}

Carlos Eduardo Facin Lavarda e Suliani Rover

\section{HISTÓRICO}

Recebido em: 05/08/2019 - Revisado por pares em: 08/10/2019 - Reformulado em: 30/04/2020 Recomendado para publicação em: 02/05/2020 - Publicado em: 30/05/2020 


\section{Apêndice A - Instrumento de Pesquisa}

Escala de Tomada de Decisão por Peritos Contadores (EDPC).

Em uma escala de 0 a 10, em que 0 (zero) representa o nível mais baixo de concordância e 10 (dez) o mais alto, marque para cada afirmação a opção que melhor representa sua opinião pessoal.

\begin{tabular}{|c|c|c|c|c|c|c|c|c|c|c|}
\hline $\begin{array}{c}0 \\
\text { Discordo } \\
\text { Totalmente }\end{array}$ & 1 & 2 & 3 & 4 & 5 & 6 & 7 & 8 & 9 & $\begin{array}{c}10 \\
\text { Concordo } \\
\text { Totalmente }\end{array}$ \\
\hline
\end{tabular}

\section{Planejamento da Perícia}

$1 \mathrm{Na}$ fase de planejamento da perícia, procuro não considerar as simulações requeridas pelas partes em seus quesitos baseados em teses judiciais.

$2 \mathrm{Na}$ fase de planejamento da perícia, em relação ao objeto da mesma, considero em primeiro lugar meus objetivos financeiros.

$3 \mathrm{Na}$ fase de planejamento da perícia, quando me deparo com fatos relevantes para a solução de determinada demanda em relação ao objeto da perícia, busco não os informar no Laudo Pericial quando estão fora do escopo dos quesitos das partes e dos pontos controvertidos do Juízo.

$4 \mathrm{Na}$ fase de planejamento da perícia, escolho não considerar a opinião dos assistentes técnicos das partes, em razão de que já defini uma metodologia que atende com eficácia ao objeto da perícia.

$5 \mathrm{Na}$ fase de planejamento da perícia, se eu identificar potenciais riscos e problemas que possam ocorrer no andamento da perícia, procuro aumentar o valor dos honorários.

\section{Execução da Perícia}

$6 \mathrm{Na}$ fase de execução da perícia, durante as diligências que realizo in loco, procuro não debater questões técnicas com os diligenciados, reservo-me a apresentar opinião apenas no Laudo Pericial.

$7 \mathrm{Na}$ fase de execução da perícia, quando me deparo com fatos novos para a solução do litígio, procuro não informá-los no laudo pericial quando estão fora do escopo dos quesitos e dos pontos controvertidos do Juízo.

$8 \mathrm{Na}$ fase de execução da perícia, após a instauração da perícia, procuro evitar a participação dos assistentes técnicos das partes, pois geralmente tenho que ajustar-me a um ou outro posicionamento prévio dos assistentes.

$9 \mathrm{Na}$ fase de execução da perícia, busco me abster de me reunir com os assistentes técnicos das partes para impedir que influenciem o trabalho pericial e prejudiquem o resultado da perícia.

$10 \mathrm{Na}$ fase de execução da perícia, quando requisito documentos em diligências e as partes não fornecem, procuro estabelecer uma relação com menor nível de comunicação com as mesmas.

\section{Conclusão da Perícia}

$11 \mathrm{Na}$ fase de conclusão da perícia, ao revisar o Laudo Pericial, priorizo a análise dos aspectos quantitativos, pois estes são os mais importantes para a formação da prova pericial.

$12 \mathrm{Na}$ fase de conclusão da perícia, ao realizar os esclarecimentos por escrito, quando percebo que as partes adotaram fortes argumentos cabíveis para desqualificar o Laudo Pericial, procuro justificar minha metodologia e não debater as teses contrárias.

$13 \mathrm{Na}$ fase de conclusão da perícia, somente respondo quesitos suplementares mediante o pagamento de honorários complementares, mesmo que isso possa causar algum desconforto em minha relação com o juiz ou com a parte que requereu.

$14 \mathrm{Na}$ fase de conclusão da perícia, quando me deparo com novos quesitos de esclarecimento em relação a fato já esclarecido, minha atitude é de ficar irritado e responder de forma mais breve possível.

$15 \mathrm{Na}$ fase de conclusão da perícia, se eu tiver que refazer ou complementar o Laudo Pericial por causa gerada pelo Juízo, somente realizo mediante complementação de honorários periciais. 